\title{
Effective factors on bank resource mobilization
}

\author{
Jafar Beikzad, Masoumeh Khodakarami, and Saeid Ghorbannejad Maleki*
}

Department of Management, Islamic Azad University, Bonab Branch, Bonab, Iran

\begin{tabular}{l}
\hline A R T I C L E I N F O \\
\hline Article history: \\
Received June 1, 2011 \\
Received in Revised form \\
November, 14, 2011 \\
Accepted 15 December 2011 \\
Available online \\
3 January 2012 \\
\hline Keywords: \\
Mobilization of Resources \\
Information and communication \\
Technology \\
Human Resources Skills \\
Internal Environment Utility \\
Bank Services Quality \\
\hline
\end{tabular}
A B S T R A C T

\begin{abstract}
The main purpose of this paper is to detect effective factors on mobilization of East Azarbaijan Agricultural Bank resources in terms of deposits absorption. In order to reaching this goal, six hypotheses have been arranged and a questionnaire including 28 questions has been designed. So after justifiability and perpetuity evaluation, the questionnaires are distributed among managers of these banks. We have analyzed the data using multi variable regression analysis, Pearson's R and Variant analyze and the results indicated that information and communication technology, service diversity, human resource skills, internal environment utility and locations are among the most influencing on resource mobilization.
\end{abstract}

\section{Introduction}

During the past few decades, there have been tremendous efforts on measuring the impact of several factors on the performance of banks. Karatepe et al. (2005) measured the service quality of banks using a multi-stage, multi-phase, and multi-sample approach. They reported on the construction of a service quality scale for retail banks in Northern Cyprus. They used parsimonious (Parasuraman et al., 1985) technique, which uses 20-item four-dimensional scale consisting of service environment (four items), interaction quality (seven items), empathy (five items), and reliability (four items) exhibits sound psychometric properties. They also discussed scale development procedures and managerial applications of the derived scale.

Lee et al. (2011) presented an empirical study of transformational leadership, team performance and service quality in retail banks. They argued that leadership style and team performance play important role for determining the service quality performance of today's banking operations in a team setting. They gathered from 192 employees and from 32 operational teams (a leader and five members in each team) in 15 retail banks in Macau, China and studied whether the five dimensions of transformational leadership had an impact on team performance with respect to team cohesion, team

* Corresponding author. Tel. + 09122582448

E-mail addresses: Saeid.Maleki141@gmail.com (S. Maleki) 
leader job satisfaction and team competence. They also argued whether the dimensions of team performance had any influence on such service quality perspectives. Their results indicated that one of the dimensions of transformational leadership and two of the dimensions of team performance influenced on service quality, significantly.

Chen (2011) investigated the service quality and consumer behavior in Taiwan by concentrating on shopping mall; choosing two high market share rate businesses from a pool for assessment according to the SERVQUAL to assess the large-scale integrated retail service quality standards. Chen reported a gap between service standard and consumer's expectation, safety facility is the most impressed and have the biggest service gap and concluded that shopping mall has leisure function. The study provided the data on Taiwan's consumer expectation of service quality required and presented the indicators for service quality improvement.

Martínez and Martínez (2010) presented some insights on conceptualizing and measuring service quality. They studied previous works in the conceptualization and measurement of perceived service quality and explained the most important models. Martínez and Martínez (2010) argued the general equations, which could be derived from each conceptualization and summarized the shortcomings and contradictions of each model. To provide a framework for understanding service quality models, they investigated the service quality paradigm from the realist and constructivist perspective and recommended the development of more creative models of service quality. They also proposed 3 various options for quantitative analysis, which minimize shortcoming of the most widely used models.

Farquhar and Panther (2008) presented an exploratory investigation on acquiring and retaining customers in UK banks. They explained how conventional banks in the UK were managing customer acquisition (CA) simultaneously while taking care of profitable customers. To find the balance between acquisition and retention and to determine marketing activities, which might support both, semi-structured interviews were performed with a small sample of senior bank staff in the UK. Their analysis revealed that banks were indeed attempting to manage acquisition with retention but encountering a range of issues as they revisit long-held strategies. They also recommended seven activities, which might contribute to a better balancing of CA with retention. Finally, they proposed a preliminary framework of marketing activities, which support both acquisition and retention.

The main goal of this paper is to study important factors influencing the mobilization resources of East Azarbaijan Agricultural bank (EAAP). The proposed study of this paper studies the effects of the following factors,

1- The impact of ICT on EAAB resources mobilization,

2- The impact of HR skills on EAAB resources mobilization,

3- The impact of diversity of bank's services on EAAB resources mobilization,

4- The impact of quality of services on EAAB resources mobilization,

5- The impact of internal environment utility effectiveness on EAAB resources mobilization (Stahl,1993),

6- The impact of banks set up location on EAAB resources mobilization (Wood, \& Vilkinas, 2004).

\section{The proposed study}

\subsection{Resources mobilization}

As we discussed earlier, there are literally many factors influencing resource mobilization and in this section we discuss some of the most important ones. 


\subsubsection{Information and communication technology}

ICT is representative of a related network of technologies defined to reach information and communicate and internet is one side of it. Internet can be used as global method for transfer capability of significant amount of information once a time, information distribution and publish mechanism and language for individual's interaction and a market for products and services.

\subsubsection{Services quality}

Services quality refers to requirements and needs supply and level of services, which satisfy customer's expectations. Based on SEVEQUAL model, customer's perceived services quality is normally measured through earned results from comparison of customer's expectations and experiences. In addition, based on SERVPERF model, services quality can be evaluated as analyze of customer's perceives examination results.

\subsubsection{Services diversity}

Diversity helps people receive variety of services, which could match to different people based on their interest.

\subsubsection{Human resources skills}

HR skills are defined as technical, perceptional and human skills, where organizations are able to read customers' interests completely and get their real meaning of whom manners. HR also represents customer's requested services quickly and tenuous (technical) and finally, HR skills means effective relation with customers, acquirement and keep them close, loyal and interested to detection of their ideas and expectation as organization.

\subsubsection{Internal environment utility}

Internal utility means peaceful and productive workplace in organizations, which leads to more human resources activity, their happiness, sadness reduction, positive services growth and finally, reaches to considered productivity.

\subsubsection{Utility of set up location}

It is situation of a branch as suitable location and distance, its state as critical place, serving services as customer's pleasure and considered points and establishment of number of branches on different locations.

\section{3- Research propositions}

1. ICT is effective on Mobilization of East Azarbaijan Agricultural Bank branches resources.

2. HR skills are effective on Mobilization of East Azarbaijan Agricultural Bank branches resources.

3. Quality of banking service is effective on Mobilization of East Azarbaijan Agricultural Bank branches resources.

4. Diversity of banking service is effective on Mobilization of East Azarbaijan Agricultural Bank branches resources.

5. Internal workplace utility is effective on Mobilization of East Azarbaijan Agricultural Bank branches resources.

6. Utility of set up location is effective on Mobilization of East Azarbaijan Agricultural Bank branches resources. 


\section{Research methodology}

As we have already explained, we have distributed 83 questionnaires among managers in EAAB, where each questionnaire contained 28 questions and they have been used for investigation. Table 1 shows a summary of our survey in terms of the number of questions, their specifications and ranking.

Table 1

Questions for each dimension in questionnaire

\begin{tabular}{|c|c|c|c|}
\hline Variables & Dimensions & Questions Rank & Questions No \\
\hline \multirow{6}{*}{$\begin{array}{l}\text { Effective factors on } \\
\text { mobilization of bank } \\
\text { resources }\end{array}$} & ICT & $1-7$ & \multirow{6}{*}{22} \\
\hline & Service quality & $8-11$ & \\
\hline & Service diversity & $12-15$ & \\
\hline & HR skills & $16-18$ & \\
\hline & Internal workplace utility & $19-20$ & \\
\hline & Utility of set up location & $21-22$ & \\
\hline \multirow{6}{*}{$\begin{array}{l}\text { Mobilization of bank } \\
\text { resources }\end{array}$} & Simple saving accounts & 23 & \multirow{6}{*}{6} \\
\hline & Individual current saving accounts & 24 & \\
\hline & Governmental current saving accounts & 25 & \\
\hline & institutional current saving accounts & 26 & \\
\hline & Short term investment accounts & 27 & \\
\hline & Long term investment accounts & 28 & \\
\hline
\end{tabular}

The instrument of data collecting is confirmed through symbolic or apparent justifiability because of using professors and expert's ideas. In order to questionnaires perpetuity examination, the Cronbach Alpha (Cronbach, 1951) Cronbach, L. J. (1951) has been used, which was estimated 0.832 and it represents that questionnaire has high coherency and it has high perpetuity.

\section{Results}

In order to analyze reached data through collected questionnaires, descriptive and deductive statistical methods have been used. At the deductive level Pearson's R method and Variant analyze and two variable regression have been used for research hypotheses examination. Table 2 shows details of our finding.

Table 2

Statistical description of research variables

\begin{tabular}{|c|c|c|c|c|c|c|c|}
\hline Variable & ICT & $\begin{array}{l}\text { Service } \\
\text { Quality }\end{array}$ & $\begin{array}{l}\text { Service } \\
\text { Diversity }\end{array}$ & $\begin{array}{l}\text { HR } \\
\text { skills }\end{array}$ & $\begin{array}{l}\text { Internal } \\
\text { workplace } \\
\text { utility }\end{array}$ & $\begin{array}{lr}\text { Utility of } \\
\text { set } \\
\text { location }\end{array}$ & $\begin{array}{l}\text { Mobilization of } \\
\text { resources }\end{array}$ \\
\hline Number & 78 & 78 & 78 & 78 & 78 & 78 & 78 \\
\hline No answer & 0 & 0 & 0 & 0 & 0 & 0 & 0 \\
\hline Average & 24.47 & 15.63 & 10.26 & 11.42 & 7.53 & 6.33 & 17.14 \\
\hline Middle & 25 & 16 & 11 & 11 & 8 & 6 & 17 \\
\hline Mode & 27 & 16 & 12 & 11 & 8 & 6 & 14 \\
\hline S.D & 2.671 & 1.873 & 2.789 & 1.516 & 1.965 & 1.835 & 2.984 \\
\hline Variant & 7.136 & 3.509 & 7.778 & 2.299 & 3.863 & 3.368 & 8.902 \\
\hline $\begin{array}{l}\text { Scope of } \\
\text { changes }\end{array}$ & 10 & 8 & 13 & 6 & 7 & 8 & 14 \\
\hline Min & 19 & 12 & 5 & 9 & 3 & 2 & 9 \\
\hline Max & 29 & 20 & 18 & 15 & 10 & 10 & 32 \\
\hline
\end{tabular}




\subsection{Deductive analyze of statistical data}

Table 3

Pearson's R test for coherency determining of resources mobilization and ICT, service quality and diversity, human resources skills, internal workplace utility and utility of set up location

\begin{tabular}{lll}
\hline Variable & Meaningfully level & Resources Mobilization \\
\hline ICT & 0.000 & 0.327 \\
Service Quality & 0.000 & 0.115 \\
Service Diversity & 0.000 & 0.465 \\
HR skills & 0.000 & 0.337 \\
Internal workplace utility & 0.000 & 0.337 \\
Utility of set up location & 0.000 & 0.330 \\
\hline
\end{tabular}

\section{Table 4}

Variant analyze related to regression model of variables

\begin{tabular}{|c|c|c|c|c|c|c|}
\hline $\mathrm{R}$ & $\mathrm{R}^{\wedge} 2$ & \multicolumn{3}{|c|}{ Adjusted $\mathrm{R} \wedge 2$} & \multicolumn{2}{|c|}{ Standard Error } \\
\hline 0.231 & 0.53 & \multicolumn{3}{|c|}{0.041} & \multicolumn{2}{|c|}{2.922} \\
\hline 0.465 & 0.217 & \multicolumn{3}{|c|}{0.206} & \multicolumn{2}{|c|}{2.658} \\
\hline 0.337 & 0.113 & \multicolumn{3}{|c|}{0.102} & \multicolumn{2}{|c|}{2.828} \\
\hline 0.337 & 0.113 & \multicolumn{3}{|c|}{0.102} & \multicolumn{2}{|c|}{2.828} \\
\hline 0.330 & 0.109 & \multicolumn{3}{|c|}{0.097} & \multicolumn{2}{|c|}{2.834} \\
\hline $\begin{array}{l}\text { Changes } \\
\text { source }\end{array}$ & $\begin{array}{l}\text { Freedom } \\
\text { rate }\end{array}$ & $\begin{array}{l}\text { Sum of } \\
\text { Squares }\end{array}$ & $\begin{array}{c}\text { Average of } \\
\text { Squares }\end{array}$ & $\mathrm{F}$ & $\begin{array}{l}\text { Confidence } \\
\text { Level }\end{array}$ & $\begin{array}{l}\text { Meaningfully } \\
\text { level }\end{array}$ \\
\hline Regression & 1 & $\begin{array}{l}36.586 \\
14.464 \\
77.780 \\
77.780 \\
74.860 \\
\end{array}$ & $\begin{array}{c}36.586 \\
148.64 \\
77.80 \\
77.780 \\
74.860 \\
\end{array}$ & $\begin{array}{c}4.285 \\
21.012 \\
9.728 \\
9.728 \\
9.318 \\
\end{array}$ & 0.95 & $\begin{array}{l}0.042 \\
0.000 \\
0.003 \\
0.003 \\
0.003\end{array}$ \\
\hline Remained & 76 & $\begin{array}{l}648.863 \\
536.985 \\
607.668 \\
607.668 \\
610.588 \\
\end{array}$ & $\begin{array}{l}8.583 \\
7.066 \\
7.996 \\
7.996 \\
8.034 \\
\end{array}$ & - & \multicolumn{2}{|c|}{$\begin{array}{l}\text { Test result: } \\
\text { Hypotheses (0) is not true }\end{array}$} \\
\hline Total & 77 & 685.449 & & - & & \\
\hline
\end{tabular}

Table 5

Coefficient of variables parameters

\begin{tabular}{llllll}
\hline \multirow{2}{*}{ Variable } & \multicolumn{2}{l}{ Not standard Coefficients } & Calculated 't" & $\begin{array}{l}\text { Meaningfully } \\
\text { level }\end{array}$ & \multirow{2}{*}{ Test results } \\
\cline { 2 - 4 } & $\begin{array}{l}\text { Criterion } \\
\text { Deviation }\end{array}$ & $\begin{array}{l}\text { Slope of line } \\
\text { "Beta" }\end{array}$ & & 0.001 & \\
& & 10.826 & 14.5584 & 0.00 & H(0) is False \\
Width from "O" & 10.429 & 12.034 & 0.00 & \\
& 2.449 & 3.908 & 0.00 & \\
\hline ICT & 2.449 & 3.908 & 0.00 & H(0) is False \\
Service Diversity & 13.738 & 11.843 & 0.00 & \\
HR Skills & 0.258 & 2.070 & 0.003 & \\
Internal W.P & 14.584 & 0.498 & 0.003 & \\
Utility & 0.213 & 3.119 & 0.003 & \\
Utility of set up loc & 0.213 & 3.119 & & \\
\hline
\end{tabular}


There is meaningful relationship between mobilization of resources and ICT, service diversity, internal workplace utility and utility of set up location. However, there is not meaningful relationship between service quality and mobilization of resources. It can be claimed that examination is meaningful as Error of 0.05 or Confidence level of 0.95. Based on concluded information from Table 5 , the mathematical equation of relations between variables are:

$\mathrm{Y}=10.826+0.258 \mathrm{ICT}$,

$Y=10.429+14.584$ Service Diversity,

$\mathrm{Y}=2.449+0.213$ Human Resources Skills,

$\mathrm{Y}=2.449+0.213$ Internal Workplace utility,

$\mathrm{Y}=13.738+0.537$ Setup location,

Therefore, it can be stated that, one unit increased on ICT, service diversity, Human resources skills, internal workplace utility and utility of set up location will cause an increase of $0.258,14.584,0.213$, 0.213 and 0.537 unit on mobilization of resources (Y), respectively. We can also conclude that location is the most important item and ICT, HRD and Internal workplace utility are of other degree of importance.

\section{Conclusion}

In this paper, we have presented an empirical analysis to study different effective factors on mobilization of East Azarbaijan Agricultural Bank resources in terms of deposits absorption. To reaching this goal, six hypotheses have been arranged and a questionnaire including 28 questions was designed. In order to receive good quality feedback, the questionnaires were distributed among managers of these banks. We have analyzed the data using multi variable regression analysis, Pearson's R and Variant analyze and the results indicated that information and communication technology, service diversity, human resource skills, internal environment utility and locations are among the most influencing on resource mobilization.

\section{References}

Chen, Y.H. (2011).The service quality and consumer behaviour analysis in Taiwan. Procedia - Social and Behavioral Sciences, 25, 16-24.

Cronbach, L. J. (1951). Coefficient alpha and the internal structure of tests. Psychometrika, 16(3), 297-334.

Farquhar, J.D., \& Panther, T. (2008). Acquiring and retaining customers in UK banks: An exploratory study. Journal of Retailing and Consumer Services, 15(1), 9-21.

Karatepe, O.M., Yavas, U., \& Babakus, E. (2005). Measuring service quality of banks: Scale development and validation. Journal of Retailing and Consumer Services, 12(5), 373-383.

Lee, P.K.C., Cheng, T.C.E., Yeung, A.C.L., \& Lai, K.H. (2011). An empirical study of transformational leadership, team performance and service quality in retail banks. Omega, 39(6), 690-701.

Likert, R. (1932). A Technique for the Measurement of Attitudes. Archives of Psychology, 140, 1-55.

Martínez, J.A., \& Martínez, L. (2010). Some insights on conceptualizing and measuring service quality. Journal of Retailing and Consumer Services, 17(1), 29-42.

Parasuraman, A., Zeithamel, V. A., \& Berry, L. (1985). A conceptual model of service quality and its implication for future research. Journal of Marketing, 49(4), 41-50.

Stahl, M.J. (1993). Achievement, power and managerial motivation: selecting managerial talent with the job choice exercise. Personnel Psychology, 36, 775-789.

Wood, J., \& Vilkinas, T. (2004). Characteristics of chief executive officers: views of their staff. Journal of Management Development, 23(3), 469-478. 